\title{
The shale revolution: Global gas and oil markets under transformation
}

\author{
By
}

Roberto F Aguilera, corresponding author

and

Marian Radetzki

r.aguilera@curtin.edu.au

marian@radetzki.biz

Curtin University, GPO Box 1987

Perth WA 6845, Australia

Luleå University of Technology, Sweden

Mail address: Skeppargatan 70

Tel +4306605538592

11459 Stockholm, Sweden

Tel +46736220771

\begin{abstract}
The shale gas and oil revolution has unexpectedly and forcefully begun to change the energy landscape in the United States. It is expected to spread beyond the US, with far reaching implications for the global energy map, but also for the macro-economy and politics of many countries. The purpose of this paper is to bring a better understanding to what prompted the revolution, to assess the production methods and associated environmental concerns, to speculate what can reasonably be expected in coming decades, and to sketch the full impact of a ripening shale revolution on the emerging economic and political policy choices for energy exporting and importing countries. We find that a large scale expansion can be expected in US shale gas and oil activities in the coming two decades. Globally, the shale leaders are likely to be countries that are already significant gas and oil producers. Setting up a policy framework to allow and promote shale development in a safe manner is a necessity for the launch of shale exploitation. The most important implication of a successful shale revolution would arguably be a downward pressure on gas and coal prices in regional markets and on the global oil price.
\end{abstract}

Keywords: Shale gas and oil; geopolitics; macro-economy

\section{Introduction}

The "shale" revolution started in the US less than ten years ago; first with fast rising production of unconventional gas, then with unconventional oil following in the steps of gas some years later. Progress is still in its infancy and knowledgeable observers point to substantial changes over coming decades. The revolution is projected to extend to around the world, leading to substantial economic and geopolitical impacts for energy producing and consuming nations. In an effort to integrate the issues, our comprehensive paper analyzes the past, present and future of shale gas and oil development. Follow us on this exciting odyssey.

The agenda of our deliberations has been organized as follows: A brief section 2 specifies the definitions of unconventional gas and unconventional oil referred to in our text as "shale". Extraction of both the gas and oil under investigation is based on the use of a common technology and we describe in a few words what is involved.

We then turn to the attainments so far. Section 3 contrasts the historically declining output levels of gas and oil in the US with the recent production achievements after the revolution gathered pace. It 
also records the changes in the US extractable resource wealth after the shale resources became economical. In Section 4 we explore the impact of the shale revolution so far on energy markets in the US and globally. Section 5 considers briefly the general economic consequences for the US from the rising gas and oil production levels.

The rest of the paper is more speculative since it turns to the future. Section 6 is devoted to the anticipated production achievements in the US, while section 7 first lists the reasons for the US lead in this field, and then broadens the vista to consider what may occur and where, as the rest of the world overcomes its inhibitions and constraints and jumps on the bandwagon. Section 8, finally, briefly sketches the policy implications for global energy markets of a successfully maturing shale revolution and explores its geopolitical and economic connotations.

\section{Definitions and technical characteristics}

The "shale" revolution is the result of technological progress that has made vast dormant gas and oil resources economically exploitable. The resources in focus of our study, referred to as shale gas, coalbed methane as well as tight gas and tight oil, typically lack strict definitions and they often overlap (EIA, 2013a, p 82). However, they are all characterized by low permeability, yielding commercially insufficient flows from vertical drilling commonly applied to traditional gas and oil deposits (Stevens, 2012, p 2). To simplify, we follow recently spreading conventions (DERA, 2012, p 17) and refer in what follows to all these resources as shale gas and shale oil.

At this time, all shale resources are referred to as "unconventional". However, it must be underlined that the "unconventional" universe comprises many resource categories other than what we have defined as shale. We avoid the "unconventional" concept in the rest of the paper because we find it subjective and unstable over time.

The energy industries employ a confusing variety of measures related to quantities and values. To promote uniformity and simplicity, this paper systematically adheres to the dominant conventions employed by BP Statistical Review of World Energy (BP, annual). All quantities, both of natural gas and oil are given in tons of oil equivalent (toe). Gas prices and costs are expressed in US dollars per million BTU (\$/MMBTU), while oil prices and costs are given in US dollars per barrel $(\$ / \mathrm{bl})$. Conversions to alternative commonly used measures are given below.

Quantities of oil and gas: 1 toe $=7.3$ barrels of oil $=1110 \mathrm{~m}^{3}$ of gas $=39200$ feet $^{3}$ of gas

Flows of oil and gas: 1 trillion feet ${ }^{3}$ of gas/year $=2.74$ billion feet $^{3}$ of gas per day $=26$ million toe/year

Values of gas: $10 \$ /$ MMBTU $=10 \$ /$ thousand feet ${ }^{3}=10 \$ /$ gigajoule $=360 \$ /$ thousand $\mathrm{m}^{3}$

Values of oil and gas: $100 \$ / \mathrm{bl}$ (oil) $=730 \$ /$ ton (oil) $=18.5 \$ / \mathrm{MMBTU}$ (gas)

The shale deposits became widely economical with the application of technologies involving horizontal drilling and hydraulic fracking to release the hydrocarbons from a much wider area than was possible with traditional vertical drilling. The breakeven prices of shale production depend importantly on the quality of the shales. Geological and engineering characteristics such as gas and oil in place, depth, permeability, porosity, organic richness, saturations and reservoir pressure are essential determinants affecting the economics of shale plays (Orangi et al, 2011).

Horizontal drilling and fracking were developed in the USA in the 1940s, but application was quite limited until these methods were perfected about the turn of the century. What is new and remarkable is the innovation associated with the development of technologies to drill horizontal 
wells that can be hydraulically fractured in multiple stages going from 200 meters $(\mathrm{m})$ apart to $100 \mathrm{~m}$ and more recently to less than $50 \mathrm{~m}$ while moving into over 60 stages per well (Aguilera et al, 2012). This, combined with the capability of drilling multi-laterals and monitoring fracture growth with microseismic data, has resulted in the shale revolution. It has involved sharp and substantial increases in extraction, so far by and large limited to the US, of the resource categories in focus of the present study.

Compared with traditional hydrocarbon production, the exploitation of shales is characterized by high well output in the first year, followed by very sharp declines. Production in the second year is typically down by $40 \%$ from the first year and by $50 \%$ in the third year, with further declines over the following production decade (IEA, 2009, p 405). This implies that numerous new wells have to be drilled continuously to maintain production at a stable level and speedy output reactions to price changes. It also means short payback periods for the investments in each well. It is being gradually realized that the new technology can also be applied to traditional hydrocarbon extraction, thereby substantially improving its productivity (Martin, 2009; Maugeri, 2013; Schlumberger, 2013).

The methods employed in the extraction of shale resources have aroused widespread environmental concerns. For example, Howarth et al (2011) indicate "3.6\% to $7.9 \%$ of the methane from shale-gas production escapes to the atmosphere in venting and leaks over the lifetime of a well. These methane emissions are at least $30 \%$ more than and perhaps more than twice as great as those from conventional gas."

On the other hand, Burnham et al (2012) assert that "shale gas life-cycle emissions are 6\% lower than conventional natural gas, $23 \%$ lower than gasoline, and 33\% lower than coal." Jiang et al (2011) conclude that "the GHG emission estimates for Marcellus gas are similar to current domestic gas." O'Sullivan and Paltsev (2012) use data from 4000 horizontal shale gas wells to claim that "it is incorrect to suggest that shale gas-related hydraulic fracturing has substantially altered the overall GHG intensity of natural gas production." Additionally, there are several other studies showing opinions and conclusions that point in different directions.

Environmental concerns have also been raised about the unsustainable use of freshwater and contamination of aquifers during the fracking process. However, advances have been made in the treatment of waste water so that some of it may be reused (Nicot and Scanlon, 2012). Also, advances in well design and casing cementing prevent the leakage of water or methane from the well (Brantley and Meyendorff, 2013). Another issue has to do with the fracturing process itself, and the nature of fluids employed. If too much pressure is employed, if the geological stresses are not fully understood, or if the formation is relatively shallow and near a groundwater source, a fracture can extend into the groundwater formation (Ripple, 2011). Given that most of the shale gas formations are relatively deep and well below groundwater formations, this negative outcome is relatively unlikely. This is supported by real fracture-growth data extracted from thousands of microseismic measurements (Fisher et al, 2011). When the top of the vertical growth of hydraulic fractures is compared with the bottom depth of ground water deposits, the conclusion is readily reached that the possibilities of these fractures reaching ground water are very low. The industry has learned far more about how to control the extent and direction of the fractures created. Given that the dominant principal stresses change from vertical (at reservoir depth) to horizontal as the ground surface is approached, the possibilities of any hydraulic fracture connecting with ground water are further diminished (Aguilera et al, 2012).

Apart from water and sand, hundreds of chemicals are included in the fluids injected. But these chemicals typically make up less than $3 \%$ (presently under $1 \%$ ) of the total. If the appropriate procedures are followed by the operator, none of these chemicals should find their way into the groundwater. Importantly, several studies have made recommendations related to the regulation of 
shale development (IEA, 2012a; US DOE, 2011; Hunter, 2011). They identify specific measures mostly related to public disclosure - to reduce environmental impacts and help assure the safety of production. They summarize that if proper procedures are followed, the economic and environmental benefits of shale will likely far outweigh any additional environmental cost associated with such shale gas extraction.

\section{US achievements to date}

Figure 1 reveals the impact on gas and oil production so far in the US. For gas, it shows a rise by $42 \%$, from 468 to 664 mtoe between 2005 and 2013. Before the revolution set in, the gas production trend was erratic but mainly downward-directed with the highest production at 560 mtoe (recorded in the early 1970s). The revolution in oil became visible only in 2008 - a three year delay compared with gas. Over the 4-year period from 2008 to 2013, oil production has risen spectacularly by 64\%; from 305 million tons to 499 million. Again, it may be useful to look at the longer production history. Over the past 40 years, there has been an almost continuous output decline. From the peak in 1970 of 534 mtoe, production fell by $43 \%$ to 305 mtoe in 2008, the year of the turnaround.

Fig 1. US natural gas and oil production, mtoe

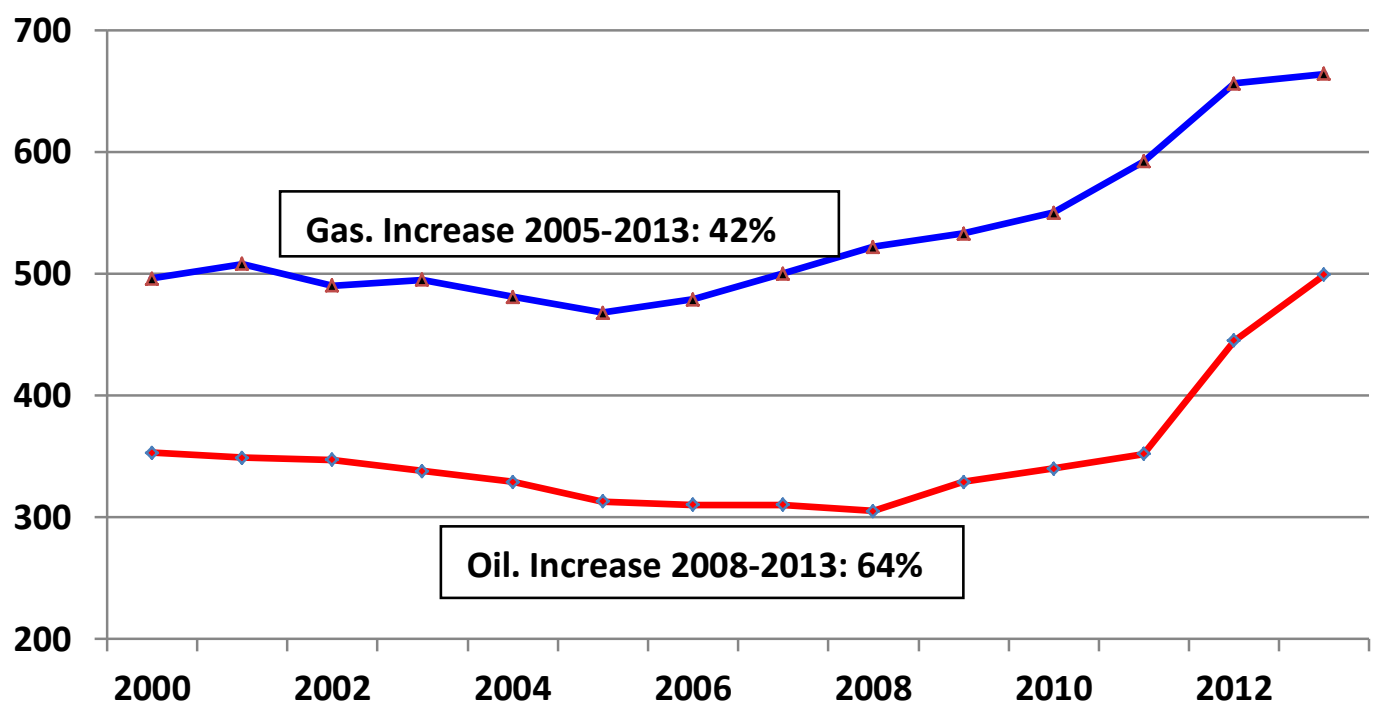

Source: EIA (2013 numbers based on EIA forecast made in Oct 2013)

Authorities like the EIA and IHS (EIA, 2013a, p 79; IHS, 2012, p 5) assert that a completely dominant proportion of the rise in production of both gas and oil noted in the figure can be attributed to the exploitation of shale resources, as defined above. While the availability of shales and the cost reducing technological breakthroughs were fundamental to the fast rising production, developments were accentuated by the sharp increase in US gas prices in 2000 and an equally strong rise in international oil prices four years later.

The technological advance that made some shale gas resources commercial in the course of the past decade has strongly boosted the interest in identifying such resources and assessing their economic potential. Prior to the shale revolution, the knowledge about shale resources was quite vague. In the past ten years, such knowledge has expanded by leaps and bounds to transform the vision of the US 
gas resource position, but very substantial uncertainties still remain. In 2003, the US National Petroleum Council assessed the country's technically recoverable shale gas resources at 990 mtoe. In 2009, the US Potential Gas Committee raised the number to 17,680 mtoe (Medlock, 2012, p 7), while the Potential Gas Committee's assessment from December 2012 lands at 27,900 mtoe - representing over half the nation's overall gas resource wealth (PGC, 2013, p 3). The most recent shale resource figure can be compared with total US gas production in 2012, $633 \mathrm{mtoe}$, and production from shales, some 440 mtoe (EIA, 2013a, p 79).

In 2010, shale gas production was a virtually exclusive US phenomenon. The country's share of global output was close to $99 \%$ (IEA, 2011a, p 197). Already in 2008, shale gas accounted for more than half of total US gas output, at average costs not higher than those for conventional gas (IEA, 2009, p 397). A more recent estimate puts the costs in a range between $\$ 3$ and $\$ 7 / M M B T U$, which is said to compare favorably with most sources of gas in the world (IEA, 2011b). Effectively, improvements in technology have reduced the costs of producing shale gas to the point where, in some instances, these costs are lower than those of conventional gas. Medlock $(2012, p 15)$ reports that one fourth of the US shale resources identified in 2009 (4,420 mtoe out of a total of 17,680 mtoe) are extractable at total costs below $\$ 3 /$ MMBTU. Costs depend importantly on the availability of liquids whose sales proceeds can be credited to the costs of gas extraction.

Large scale exploitation of shale oil in the US is even more recent than in gas and knowledge about the recoverable resource base is highly incomplete. An analysis by the Energy Information Administration relating to 2009 (EIA, 2011a) put the US total in that year at 3.3 billion tons, but by 2010, the figure had been adjusted to 4.6 billion (IEA, 2012a, p 108), which is $25 \%$ more than the country's overall proved oil reserves. US production of shale oil spectacularly doubled from 25 million tons in 2010 to an estimated 50 million in 2012 (IEA, 2012a, p 106, 108), and rose sharply higher in 2013. The shale oil resources under exploitation have costs typically lower than Canadian oil sands or Brazilian ultra-deep crude, both of which are estimated to have average production costs of about $\$ 70$ per barrel (GEA, 2012, p 445). Shale oil exploitation in North America becomes broadly economical at oil prices somewhat below $\$ 50$ per barrel (IEA, 2011a, p 69). Production outside the US has remained insignificant so far.

\section{Impacts on US and international energy markets}

High transport costs along with absent transport infrastructure and restrictive trade policies explain the substantial differences between gas prices recorded in regional markets. Natural gas pricing around the globe has historically been rather divergent; a comprehensive discussion of the different economic market structures that have prevailed in regional markets may be found in Dahl (2004). North America has been the most competitive among the regional gas markets. Most natural gas is sold there under pricing arrangements that are guided by the price of natural gas quoted at Henry Hub $(\mathrm{HH})$, Louisiana. European natural gas pricing has been largely based on links to oil products, rather than the gas-on-gas pricing as in North America since the 1980s. There is some movement in Europe away from oil-based pricing, but the progress toward hub-based, gas-on-gas pricing is slow. In the early 2010s, LNG reaches the Asian market from a wide range of producing regions. Demand also spread beyond Japan, the former dominant market, to Taiwan, South Korea, and China, with additional developments underway in several other countries in the region. Natural gas pricing in Asia has historically been tied contractually to crude oil, and only recently have alternatives been introduced.

Figure 2 reveals that the deviation between the US and other markets rose sharply from 2009 onwards, as the US shale output expansion gained speed. The figure also demonstrates US prices in 2009-2013 far below the levels that prevailed in 2003-2008, prior to the price impact of rising supplies. 
Fig 2. Natural gas prices*, nominal \$/MMBTU. 2013 = January to September.

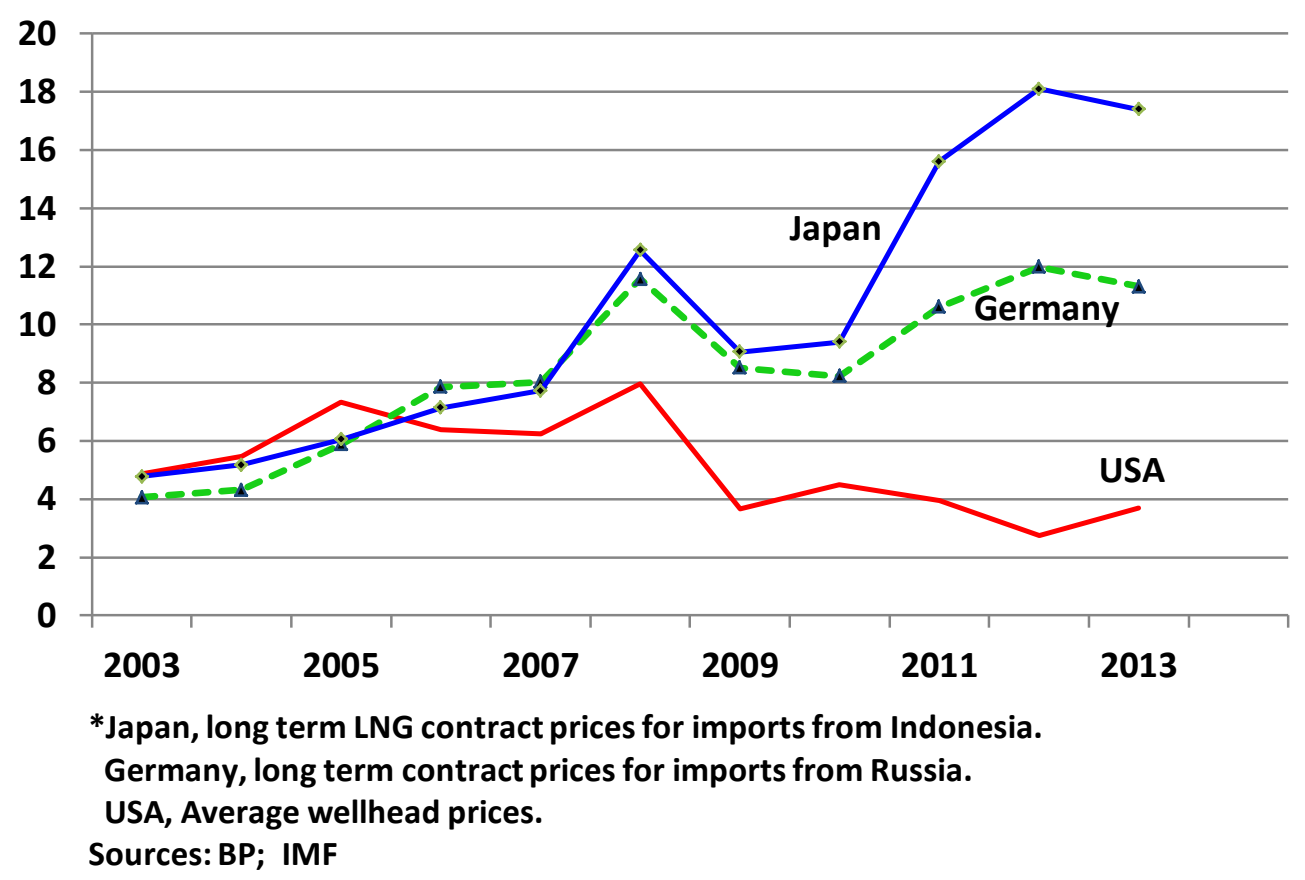

As noted, an IEA study from 2011 assessed that plentiful shale gas resources could be extracted in the US at costs within a range of \$3-7 (IEA, 2011b). One might then reasonably have expected shale output to decline or at least to stagnate with prices at or below $\$ 4$ from 2009 onwards. Indeed, there was a sharp reduction in the number of drilling rigs predominantly devoted to shale gas, from about 1500 in 2008 to less than 900 in 2011, as drills were shifted to shale oil. The numbers rose for the latter from 400 to 900 in the same period (IEA, 2011a, p 69), given that oil prices had not been affected by the shale revolution. Astonishingly, however, the reduced number of rigs devoted to gas had no apparent impact on gas production growth. Cost reducing technological developments in shale gas production progressing by leaps and bounds, dramatically increasing efficiency in drilling operations, provide a plausible explanation to this counterintuitive observation (EPRINC, 2011, p 2). Overall US gas output per drill in use rose more than threefold between 2008 and 2012 (EPRINC, 2013). A move to the exploitation of wetter resources with greater returns from gas liquids, and hedging to secure the earlier high prices several years into the future, of course provide additional explanations to the gas output performance in the wake of falling gas prices.

To US gas users, the cheap gas has been a bonanza. For example, the viability of the US petrochemical industry has strengthened greatly, to the chagrin of its European and Japanese competitors. A sizable shift from coal to gas has occurred in power generation, reducing $\mathrm{US} \mathrm{CO}_{2}$ emissions by more than 10\% between 2007 and 2012 (Hasset and Mathur, 2013, p 13) and at the same time establishing a surplus of coal supply. The development of shale gas has prompted several adjustments in the US coal market. Between 2007 and 2012, coal prices fell and production responded by a decline of $11 \%$, corresponding to 130 million tons. At the same time, exports more than doubled to 126 million tons (EIA, 2013b), absorbed in the main by European consumers (IEA, 2012a, p 78). Germany, in particular, has expanded its coal demand in the face of a decision to decommission the country's nuclear power. 
Increasing domestic gas supplies have sharply cut US gas import needs. Between 2007 and 2012, total imports fell by $32 \%$ to 80 mtoe, while LNG imports reduced by $78 \%$ to $4.4 \mathrm{mtoe}$ (BP, annual), thereby idling many existing LNG import facilities and prompting their conversion towards exports. Substantial LNG sales abroad are under consideration. By 2012, eight LNG export projects with a total capacity of 150 mtoe were being planned (Stevens, 2012, p 7), with completion beginning about 2015 (IEA, 2012a, p 77). When in full use, this capacity would add about 50\% to 2012 global LNG exports (BP, annual). License to export has so far been granted to four of the projects (capacity 60 mtoe per annum) with several others likely to follow (Abiteboul, 2012; Platts, 2013). Domestic opposition against LNG exports has been voiced by the argument that such exports would raise domestic prices, but the assessed size of the price increase, 2-11\% under plausible export assumptions (Ebinger and Avasarala, 2013, p 7), does not appear to be overly threatening to gas consumers. In a study for the US Department of Energy, NERA Economic Consulting (2012) further finds that the US stands to gain net economic benefits from LNG exports.

The collapse of US LNG imports has had a dampening impact on prices in Europe and Asia, as LNG supplies intended for the US had to be redirected to other destinations. This impact was temporarily reduced by increased Japanese demand following the Fukushima nuclear disaster. Russian gas export monopoly, Gazprom, whose sales are dominated by long run contracts with prices tied to high priced oil, has been forced to make painful adjustments due to the much lower spot prices in the European market. Customers have used existing contract flexibilities by taking minimum quantities and demand a complete renegotiation of terms as contracts expire. To safeguard its Polish market, Gazprom in 2012 accepted a 15\% price reduction across the board in its contract with Poland. The shale gas boom is hitting this company's production growth prospects, pricing power and revenues (Vihma, 2013, p 7). A vision of emerging excess supplies of gas as the Japanese situation normalizes and the US starts exporting LNG is bound to have a depressive effect on gas prices in all the regional markets while increasing the role of spot prices (Robinson and Qinhua, 2013). However, it is noteworthy that prices in the Asia Pacific are locked into long term contracts and delinking from oil could be time-consuming and complex.

The repercussions so far of the US shale oil revolution on oil markets and on oil consumers have been much less far-reaching. The oil market is truly global, so the impact of changes that have occurred in the US, for instance on prices, becomes highly diluted. The main change related to the oil market is a decline in US import needs. Abstracting from products trade and focusing on unrefined oil, it can be noted that the 2008 US consumption exceeded domestic output by 570 million tons. This volume had to be procured from abroad. By 2012, the difference had shrunk to 470 million tons; the shrinkage predominantly due to an increase in domestic shale output. In 2012, however, the US was far from self-sufficient and even continued shale oil expansion is judged unlikely to bring about such selfsufficiency in the foreseeable future (FT Alphaville, 2012). The declining US import needs have given an intriguing boost to oil tanker trade by increasing the average distance travelled by oil in international trade. With falling US imports, the short distances for delivering Venezuelan and Angolan oil to the US East Coast are being swapped for more extended distances in Asian destinations (FT, 2013a, p 13).

Shale oil resources in the US become economically exploitable at oil prices between $\$ 45$ and 70 , with higher quality shales such as the Bakken and Eagleford close to the lower bound (Rystad Energy, 2012). This is somewhat less than the price level required by Canadian oil sands and substantially below the 2011-2013 prices for crude oil. The Canadian Energy Research Institute carried out a study on oil sands production costs that indicates breakeven prices in the range $\$ 45$ to $\$ 90$ per boe. (CERI, 2012). Liquids from shale gas are much cheaper to produce, ranging from around $\$ 10$ to $\$ 40$ per boe (IEA, 2012b). 


\section{The shale revolution: its general benefits to the US economy}

The benefits can be subdivided into those generated within the gas and oil sector and the ones resulting from lower gas prices for the rest of the economy. An important consideration when evaluating both cases is the existence since several years of a considerable idle capacity in the US economy, in the labor markets as well as in the physical capital facilities. This excess capacity can be regarded as a free resource when taken into use. We draw heavily on a recent study (IHS, 2012) in establishing the size of the benefits in 2012, emerging within the gas and oil sector. IHS is a well known consultancy focusing since many years on the economics of energy. Where no other reference is provided, this is the source to the numbers we present.

IHS estimates the total 2012 investments in shale gas and shale oil at $\$ 87$ bn $(0.6 \%$ of US GDP, assessed at $\$ 15,700 \mathrm{bn}$ in the same year), of which $\$ 47 \mathrm{bn}$ are devoted to gas. These investments, along with shale production operations, yield an overall direct employment of 360,000 . This rises to 1.75 million (corresponding to $1.3 \%$ of total US employment of $135 \mathrm{~m}$ ) when indirect and induced employment effects are taken into account, with one half accounted for by shale gas. The labor income has been assessed at $\$ 125 \mathrm{bn}$, with a much higher value added at $\$ 240 \mathrm{bn}$, given this activity's elevated capital intensity. By the value added measure, the shale sector's contribution to GDP was about $1.5 \%$ - a highly impressive figure. Given the relative self-sufficiency of the US in technology and other inputs, leakage abroad would be limited and most of the benefits would remain at home.

The overall fiscal revenue of the shale activities in the form of employee income tax, corporate profits tax and royalty payments work out at $\$ 62 \mathrm{bn}$. To get a perspective of the significance of the fiscal revenues, we may note that the Federal Government's share, $\$ 31 \mathrm{bn}$, would suffice to fund $80 \%$ of the budgets of the Dept of Interior, Dept of Commerce and NASA combined.

These are the effects of the shale activities in 2012, but IHS envisages such benefits to endure and grow year by year as the shale operations continue their growth and development. By 2035, constant money investments would have grown to $\$ 350 \mathrm{bn}$ and fiscal revenues to $\$ 125 \mathrm{bn}$, while the sector's overall employment effects would have risen to 3.5 million.

We noted earlier that the lower gas prices greatly strengthened the competitiveness of the US petrochemicals, promoting that sector's expansion. But the bonanza from low gas prices would be felt far beyond petrochemicals. Producers of fertilizer and steel, heavy users of natural gas, would equally benefit. On a more general level, Dow Chemicals reported in 2012 that a variety of US manufacturers announced $\$ 90$ bn of new investments in the US to 'take advantage of its cheap natural gas' (Vihma, 2013).

\section{Anticipated future US prospects and their implications}

Judging from the numbers provided by the IHS study presented in the preceding section, a very large scale expansion can be expected in US shale gas and shale oil activities in the coming two decades. This view is corroborated in some measure by the most recent projections formulated by the US Department of Energy and the International Energy Agency.

On the wave of the shale revolution, the US overtook Russia in 2009 as the world's largest gas producer. As noted, the US gas output increased by $42 \%$ in the eight year period between 2005 and 2013 to 664 mtoe in the latter year. Russian output is expected to rise by less than $5 \%$ between 2005 and 2015 to reach 550 mtoe. Both IEA and EIA envisage continued gas production expansion in the US, though at far slower rates than in the recent past. IEA (2012a, p 138) forecasts 2035 US gas output at 720 mtoe, only 14\% above that of 2012. EIA's projections reach 815 mtoe in 2035 (EIA, 
2013a, $\mathrm{p} 147$ ) an addition of another $30 \%$ over 23 years. Both agencies see most of the forthcoming expansion coming from shale gas. Both also predict US LNG exports to emerge by 2020.

The shale revolution is envisaged by both agencies to continue in oil too, at least until 2020, but as with gas, at a much slower rate than in the recent past. By 2020, the US is seen to become the world's largest producer at some $530 \mathrm{mt}$, but remarkably, from then on the oil shale revolution is seen to be exhausted and output starts a long run decline until 2035 (the end of the forecast period). The country never becomes self-sufficient in oil as imports persevere through the 2035 time horizon. The EIA's output growth projections are summarized in table 1 . The contrast between the actual and the projected numbers is clearly revealed.

\begin{tabular}{|c|c|c|c|c|}
\hline & $2008-2012$ & $2012-2020$ & $2020-2030$ & 2030-2035 \\
\hline Gas & 4.9 & 1.1 & 1.1 & 1.0 \\
\hline Oil & 7.4 & 3.4 & -1.4 & 0 \\
\hline
\end{tabular}

The IEA makes no price projections, but the EIA foresees prices rising until 2035 to $\$ 6.32 /$ MMBTU for gas (+59\% from 2011) and to $\$ 145 /$ bl for oil (+31\% from 2011), all in constant 2011 dollars.

We find the anticipated weak or absent output growth and rising prices surprising against the background of the experiences of the recent past when shale resources were repeatedly upgraded, productivity rose much faster than expectations and costs and prices were declining. The temporary nature of the revolution reflected in the projections is contradicted by the US shale resource wealth already identified and even more by the likely discoveries from ongoing prospecting operations. The dynamics of technological progress and recoverable resource wealth quantities are astounding: Between 2008 and 2013, the assessed size of the US Bakken shale oil formation rose more than fivefold to 2.5 billion tons (IEA, 2013, p 169). We challenge the official forecasts and maintain a more optimistic outlook.

Irrespective of which vision proves correct, it is clear that the US lead in the revolution will make the country less dependent on foreign fossil fuel supply and will expand the policy options for assuring the nation's consumption needs.

\section{Will the revolution spread globally?}

The likely answer is yes, since the resource base is widely spread and there is potential for diffusion of technology to the rest of the world (Fattouh, 2013), even though we know little about the quality of the resources compared with those in the US. The crucial question is when the revolution will occur in different country categories. Our attempt to deal with this question begins by illuminating the reasons for the US lead in the shale revolution and how long this lead is likely to persevere.

A brief list of circumstances suffices to explain what caused the US to take and to maintain a vanguard position in this field. First, of course, is a favorable resource wealth, though many countries share this characteristic with the US. A long history of large scale gas exploitation guaranteed a technological prominence and a physical infrastructure for conventional gas exploitation. Both could be easily converted to the needs of shale gas. The general institutional infrastructure needed to promote innovative entrepreneurial activities in general was internationally prominent and could be readily applied for the development of shale gas. Sparse population reduced environmental 
sensitivities. Another facilitating circumstance is that US legislation grants the landholder ownership rights to what is underground, a rule not applied by many other countries. The US legislation avoids land rights problems, since the landholder is in control and benefits from royalty payments. The country's long tradition of small, adventurous exploration enterprises helped to speed up the revolutionary process. The bureaucratic energy giants were initially slow to move into the field, but became eager once the exploration firms identified the geological and economic potentials and offered to sell the discovered deposits. All these features help to understand why the US took a lead in the revolution and why most other countries are lagging far behind.

Global shale gas resources are poorly known, those of shale oil even less. A study commissioned by EIA and published in April 2011 (EIA, 2011b, p 4) but using data not more recent than those available in 2009 , lists the total technically recoverable volume at 171,600 mtoe, of which $13 \%$ is in the US. This number is in the same ballpark as the global conventional proved gas reserves of 190,000 mtoe and represents a multiple of 57 years' global 2012 gas production of 3.033 mtoe (BP, annual). Since the study does not cover some important regions, notably Russia, the Middle East and South-East Asia, its numbers must be far below the truly global level.

A more recent assessment, published in June 2013 (EIA, 2013c, p 2), estimates a global shale gas total of 189,800 mtoe, which is about a $10 \%$ increase compared with the 2011 study. The number of countries assessed has increased from 32 to 41 . The recoverable shale gas resources are widely spread, with China accounting for $15 \%$, Argentina $11 \%$, Algeria 10\%, US 9\%, Canada $8 \%$, Mexico $7 \%$, Australia 6\%, South Africa 5\% and Russia 4\%. Brazil, Venezuela, Poland, France and Libya are other countries with significant resource potential.

IEA (2012a, p 134) assesses the global shale gas total at 295,000 mtoe, and 235,000 mtoe excluding North America, but provides only continental and no national subdivisions. The higher IEA figures are are plausibly explained by its broader geographical coverage.

Which among the shale gas resource holders outside the US, listed in the EIA studies, are likely to take the lead in exploiting these resources and when is their revolution likely to begin? In reviewing this issue, the EIA points to the build-up of necessary infrastructure as the most extended delaying factor. It may take up to 10 years if infrastructure is to be developed from scratch. Hence, the leaders are likely to be countries that are already significant conventional gas producers, since the existing infrastructure can easily be adjusted to the exploitation of shale gas.

Canada, with its long history of oil and gas industry experience, also has a strategic advantage in shale development. Canadian natural gas production currently ranks third in the world, with shale gas steadily increasing its share. The Canadian Association of Petroleum Producers (CAPP, 2013) expects Western Canadian unconventional gas (shale) to become the nation's dominant source of gas supply after 2020. According to Bernstein Research, Australia is likely to emerge as the most prolific shale producing nation outside North America due to the similarities in above ground factors between the two regions (SPE News, 2013).

In China, with an impressive resource wealth, a sizable conventional gas production and with the authorities very keen, the gas industry does not expect to get the shale revolution going on a large scale until after 2020 (Fan Gao, 2012, p 22). By 2035, however, shale gas is seen to account for $70 \%$ of total gas output (IEA, 2012a, p 142). Water shortages, currently necessary for fracturing, also pose a challenge in China, as well as Australia.

Developments in Argentina, a country whose resource base is almost equal to that of the US, had been stalling for reasons related to the country's politics. For instance, there is the uncertainty among foreign investors aroused by the government's recent takeover of Spanish Repsol. 
Nevertheless, US Chevron recently reached a final agreement to invest $\$ 1.24$ billion to develop the Vaca Muerta shale field along with YPF, the state owned energy firm (FT, 2013b).

Progress in Europe is hesitant, importantly on environmental grounds. France has banned shale gas operations, possibly as a measure to prevent the destruction of capital invested in the nuclear sector. Bulgaria too has banned shale gas drilling, perhaps aided by Russian efforts to safeguard its gas exports. Europe's high population density and environmental sensitivity could plausibly make the continent a laggard in the shale gas revolution. Furthermore, subsurface ownership rights belong to the state in most European countries, which means landowners have reduced incentive to allow drilling on their lands. Lastly, many European companies are state-owned and thus have differing goals in comparison to the small, specialized and independent companies operating in the US. Nevertheless, given the enticing advantages reaped by the US (see section 5), it is an open question whether Europe can resist in the longer run.

Poland, however, with Europe's largest shale gas resource wealth (EIA, 2013c, p 1-7) is pushing ahead at full speed despite Exxon's recent exit (see next paragraph). The country has a strong incentive in its high dependence on gas from a neighbor inclined to use the supply of gas for political ends. A note from the Polish Ministry of Treasury (2013) reports current exploration in shale gas as one of Poland's key investment activities, with the involvement of a number of both Polish and foreign parties. An internationally attractive fiscal package is in the late stages of preparation, but the details of environmental rules to be applied to shale gas remain to be formulated. Nevertheless, 2015 is seen as a plausible date for launching shale gas extraction.

We have noted in an earlier section that Russia, with $22 \%$ of conventional gas reserves and $21 \%$ of 2011 global exports, was feeling threatened by the US shale revolution. It has been reported, conspiratorially, that Russia has persistently attempted to defer the progress of the revolution by financing environmental groups to lobby against shale gas. Russia is also claimed to have used its domestic energy resource wealth to dissuade international energy companies from engaging in shale. Exxon's exit from Poland in 2012 has been seen as a precondition for concluding the company's lucrative agreement with Rosneft to explore and exploit the Arctic (Tucker, 2012). The launch of the Global Shale Gas Initiative in 2010, by the US Department of State (EIA, 2011b, p 5), could be seen as a political measure to counter Russia's restraining actions, and make the world less dependent on Russian gas. The initiative is to assist potential shale gas producing nations with resource assessments, technology transfer and advice on the buildup of institutional infrastructure.

The exploitation of shale oil resources outside the US will likely lag that of shale gas. A study commissioned by the German Federal Institute for Geosciences and Natural Resources (DERA, 2012, $\mathrm{p} 17,44)$ notes that exploration for such resources has barely begun. Though the global total presented is not disaggregated by country, the technically extractable resources, 87,000 million tons, correspond to almost $40 \%$ of global proved oil reserves. Estimates are revealed for selected countries including China (41,000 million tons) and Venezuela (34,000 million tons), who dominate the total (the US figure is given at only 3,000 million tons). As exploration gains speed, the volumes and the geographical spread are likely to rise. The 2013 study by the EIA (2013c, p 2) provides a smaller global shale oil technically recoverable total of 47,000 million tons. Russia accounts for the largest share at $22 \%$, followed by US 17\%, China 9\%, Argentina 8\%, Libya 8\%, and Venezuela and Mexico with $4 \%$ each. The diverging estimates between the studies reveal the uncertainty, complexity and subjectivity inherent in such estimation at this time, though it can be reasonably concluded that the global shale oil endowment is vast.

For all the reasons discussed above, a significant global shale impact will take time and will likely be unevenly spread. On current visions by the more cautious energy specialists, it will not be until the 2030 s before the effects are fully felt. But then, one must not forget the astonishing suddenness and 
force of development in the US over the past decade. Similar surprises cannot be precluded for other nations with sizable shale resources.

The following exercise is no more than a thought experiment to gauge a possible impact of the international shale revolution spread (as presented in table 2). We start by summarizing the US accomplishments in 2005-2013, the early stage of the revolution, and conservatively disregard all future US achievements that will undoubtedly come. With roughly a $9 \%$ share of global shale gas resources (EIA, 2013c) and a 4\% share of shale oil resources (DERA, 2012), the US in the eight years expanded its gas output by $196 \mathrm{mtoe}$ and oil output by $186 \mathrm{mt}$.

\begin{tabular}{|l|r|r|r|r|r|}
\hline \multicolumn{7}{|l|}{ Table 2. Speculative non-US shale impact. 2015-2035, mtoe } \\
\hline & $\begin{array}{r}\text { Global } \\
2012 \\
\text { output }\end{array}$ & $\begin{array}{r}\text { Global rise, } \\
20 \text { years } \\
(1991-2011)\end{array}$ & $\begin{array}{r}\text { US share of } \\
\text { shale } \\
\text { resources }\end{array}$ & $\begin{array}{r}\text { US production } \\
\text { rise, 8 years } \\
(2005-2013)\end{array}$ & $\begin{array}{r}\text { ROW } \\
\text { production } \\
\text { rise, 20 years } \\
(2015-2035)\end{array}$ \\
\hline Gas & 3034 & 1130 & $9 \%$ & 196 & 2170 \\
\hline Oil & 4120 & 850 & $4 \%$ & 186 & 4650 \\
\hline
\end{tabular}

Assume, then, that the rest of the world (ROW) is equally successful as the US was between 2005 and 2013 in exploiting its share of the resources between 2015 and 2035; i.e. with a substantial delay and at less than half the speed attained by the US. In our view, this is on the conservative side but nevertheless would yield a ROW 2035 shale gas output of 2,170 mtoe and a shale oil output of 4,650 $\mathrm{mt}$ in the same year.

The importance of these supply additions can be measured in many ways, but they are truly stunning. The projected gas expansion corresponds to $71 \%$ of current global output; the 2035 ROW shale oil output works out greater than total global oil production in 2012! The 20-year output growth projections for ROW shale gas given in the table are twice as large as the global production rise in the preceding 20 years; for oil they are more than 5 times as large! Note that future conventional output increases, such as those following from recent discoveries of gas in the Eastern Mediterranean, have to be added to those from shale gas and shale oil, to obtain the global 2035 aggregates. Were our speculation to materialize, the total change over the coming twenty years would be revolutionary indeed - a game changer for the gas and oil markets.

Is our exercise at all meaningful? We think that, if nothing else, it is a useful widener of concurrent visions and perspectives of what plausibly could occur.

\section{Policy implications of a successfully maturing global shale revolution}

A number of implications are likely to follow from the dynamic supply additions yielded by a successful shale revolution. With all the uncertainties about how the revolution will change output and where, it seems to us to be futile to provide more than a summary sketch of likely consequences.

The first, and arguably most important implication, would be a downward pressure on the high gas prices in regional markets outside North America and on the global oil price. The growth and geographical diversification of supply would promote competition among suppliers and make it more difficult for producers to manipulate the market to their advantage or for their governments to use energy sales in pursuit of political ends. 
Many fossil producing countries would face reduced export earnings. Nations whose exports are dominated by fossil fuels, and whose own shale expansion did not compensate for the income losses due to lower gas and oil prices, would face the need for economic diversification and sometimes painful macroeconomic adjustments to restore balance. Successful shale developers could reap benefits similar to those bestowed on the US in its progress with shale in recent years.

Energy importing countries, but not necessarily their energy consumers, would benefit from the lower prices. Importing governments could plausibly introduce policies for import levies or consumption taxes to strengthen their budgets or reduce energy demand growth.

Coal producers around the world would face sharpened competition from gas and oil, leading to a shrinking market and lower coal prices. High cost coal producers would be forced to close.

Efforts to develop renewables for the purpose of climate stabilization and energy security would become more costly in consequence of the shale revolution. Policies to provide larger subsidies for wind, bio and solar would be needed to assure their market position in the face of lower fossil prices. However, an increased market share of natural gas, the cleanest fossil fuel of all, has the potential to lessen relative carbon emissions compared with coal and oil. In Europe, reduced coal prices would lead to increased use of coal for electrical power generation. Though this would not affect total carbon emissions in the trading sector (since they are determined by emissions caps in the EU Emission Trading System), it would likely drive up the price of emissions allowances.

There would be hard to fathom international political repercussions from a declining importance of the Middle East as a dominant world fossil supplier. The heavy US diplomatic and military presence in the region is likely to be questioned when the country's dependence on Middle East gas and oil is reduced. As economists, we suffer from a lack of competence to explore the likely US reactions and the political repercussions within the region from a partial US withdrawal. Furthermore, it is possible that oil from the Middle East would find increased market share in the still growing Asian demand centers whose own shale industries are not likely to develop meaningfully for a few decades. There could be important political and economic reactions from the powerful nations within the Asia region, e.g. China, as they seek to secure oil supply from the Middle East. With regard to shale gas, it is likely that the Middle East holds vast volumetric endowments as well. This would be beneficial in satisfying rapidly increasing domestic consumption.

Exciting times can be expected ahead.

\section{References}

Abiteboul J (2012), "What is the Time Line for LNG Exports from the USA?", presentation to the Flame Conference in Amsterdam, 12 April.

Aguilera RF, RD Ripple and R Aguilera (2012), "Link between Rocks, Hydraulic Fracturing, Economics, Environment, and the Global Gas Portfolio", SPE Canadian Unconventional Resources Conference, CURC 2: 1044-1068.

BP (annual), BP Statistical Review of World Energy.

Brantley SL and A Meyendorff (2013), "The Facts on Fracking", The New York Times, March 13, http://www.nytimes.com/2013/03/14/opinion/global/the-facts-on-fracking.html 
Burnham A, J Han, CE Clark, M Wang, JB Dunn and I Palou-Rivera (2012), "Life-cycle greenhouse gas emissions of shale gas, natural gas, coal, and petroleum", Environmental Science and Technology 46: 619-627.

CAPP (2013), Canadian Natural Gas Production Forecast, Canadian Association of Petroleum Producers, April 13, http://www.capp.ca/forecast/Pages/default.aspx.

CERI (2012), Canadian Oil Sands Supply Costs and Development Projects 2011-2045, Canadian Energy Research Institute Study 128, Calgary, Canada.

Dahl CA (2004), International energy markets: understanding pricing, policies, and profits, PennWell Corporation, Tulsa, Oklahoma.

DERA (2012), Energy Study: Reserves, Resources and Availability of Energy Resources 2012, Deutsche Rohstoffagentur, Hannover.

Ebinger C and G Avasarala (2013), "The Case for US LNG Exports", Oxford Energy Forum, Issue 91.

EIA (2011a), Review of Emerging Resources: US Shale Gas and Shale Oil Plays, Energy Information Administration, Washington DC.

EIA (2011b), World Shale Gas Resources: An Initial Assessment of 14 Regions Outside the US, April.

EIA (2013a), Annual Energy Outlook, Energy Information Administration, Washington DC.

EIA (2013b), Monthly Energy Review, Energy Information Administration, Washington DC, April.

EIA (2013c), Technically Recoverable Shale Oil and Shale Gas Resources: An Assessment of 137 Shale Formations in 41 Countries Outside the United States, Energy Information Administration, Washington DC, June.

EPRINC (2011), "Natural Gas Industry Fakes the Moon Landing" Briefing Memorandum, Energy Policy Research Foundation, Washington DC, July 1.

EPRINC (2013), "Prospects for LNG Exports from North America", presentation at JOGMEC Petroleum Seminar, Tokyo, February 7.

Fan Gao (2012), "Will There Be a Shale Gas Revolution in China by 2020?", NG61, Oxford Institute for Energy Studies, April.

Fattouh B (2013), "The US Tight Oil Revolution: What Kind of a Revolution?", Oxford Institute for Energy Studies, presentation at the Saudi Association for Energy Economics, May 28.

Fisher K and N Warpinski (2011), "Hydraulic fracture-height growth", SPE paper 145949, Annual Technical Conference and Exhibition. Denver, Colorado: October 30 - November 2.

FT Alphaville (2012), "US Shale Oil Abundance: Bernstein vs the IEA", Financial Times Alphaville, November 19, http://ftalphaville.ft.com/2012/11/19/1266853/us-shale-oil-abundance-bernstein-vsthe-iea/

FT (2013a), "Oil Tanker Trade Soars on Back of US Boom”, Financial Times, May 13. 
FT (2013b), “Chevron back in Argentina with \$1.2 billion deal”, Financial Times, July 17.

GEA (2012), Global Energy Assessment: Toward a Sustainable Future, Cambridge University Press, United Kingdom.

Hasset K and A Mathur (2013), "Benefits of Hydraulic Fracking", Oxford Energy Forum, Issue 91.

Howarth RV, R Santoro and AI Ingraffea (2011), "Methane and the greenhouse-gas footprint of natural gas from shale formations", Letter published with open access at Springerlink.com, 13 March.

Hunter T (2011), Regulation of Shale, Coal Seam and Tight Gas Activities in Western Australia, Bond University, Queensland, July.

IEA (2009), World Energy Outlook, International Energy Agency, Paris.

IEA (2011a), Medium Term Oil and Gas Markets, International Energy Agency, Paris.

IEA (2011b), Are we Entering the Golden Age of Gas?, International Energy Agency, Paris.

IEA (2012a), World Energy Outlook, International Energy Agency, Paris.

IEA (2012b), Medium Term Oil Market Report, International Energy Agency, Paris.

IEA (2013), Resources to Reserves, International Energy Agency, Paris.

IHS (2012), America's Energy Future: The Unconventional Oil and Gas Revolution and the US Economy, Englewood, Colorado, USA, October.

Jiang M, M Griffin, C Hendrickson, P Jaramillo, J VanBriesen and A Venkatesh (2011), "Life cycle greenhouse gas emissions of Marcellus shale gas", Environmental Research Letters 6 (3).

Martin A (2009), "Appropriate Hydraulic Fracture Technologies for Mature Oil and Gas Formations", SPE Distinguished Lecturer Program, 2008-2009 Season.

Maugeri L (2013), “The Shale Oil Boom: A US Phenomenon”, Discussion Paper \#2013-05, Harvard Kennedy School, June.

Medlock KB (2012), "Shale Gas, Emerging Fundamentals, and Geopolitics", Presentation at James A Baker III Institute for Public Policy, Rice University, June 14.

NERA Economic Consulting (2012), Macroeconomic Impacts of LNG Exports from the United States, Washington D.C., USA, December.

Nicot JP and BR Scanlon (2012), "Water Use for Shale Gas Production in Texas, US", Environmental Science and Technology 46: 3580-3586.

Orangi A, NR Nagarajan, MM Honarpour and J Rosenzweig (2011), "Unconventional Shale Oil and Gas - Condensate Reservoir Production, Impact of Rock, Fluid, and Hydraulic Fractures", SPE Paper 140536, SPE Hydraulic Fracturing Technology Conference and Exhibition, Woodlands, Texas, January 24-26. 
O'Sullivan F and S Paltsev (2012), "Shale Gas Production: Potential Versus Actual Greenhouse Gas Emissions", Environmental Research Letters 7 (4).

PGC (2013), Potential Gas Committee Press release, Colorado School of Mines, Golden, Co, April 9.

Platts (2013), "US DOE approves Dominion Cove Point plans to export LNG to non-FTA countries", Platts McGraw Hill Financial, September 11.

Polish Ministry of Treasury (2013), Economic News, Warsaw, April 19.

Ripple RD (2011), "There's more to coalseam gas than Gasland", The Conversation, May 26, http://theconversation.com/theres-more-to-coal-seam-gas-than-gasland-1477

Robinson D and X Qinhua (2013), "OIES-Renmin Roundtable Conference on Implications for China of North American Energy Independence: Summary of Discussions", Oxford Institute for Energy Studies and Renmin University of China, Beijing, Mar 27.

Rystad Energy (2012), North American Shale Analysis, Oslo, Norway, http://www.rystadenergy.com/ResearchProducts/NASAnalysis

Schlumberger (2013), Conventional Sandstone Stimulation, Schlumberger Ltd, Houston, http://www.slb.com/services/completions/stimulation/sandstone.aspx

SPE News (2013), "Australian shale potential No. 1", SPE News Australasia, May 21, http://www.spenewsaustralasia.org/article.aspx?p=1\&id=2020

Stevens P (2012), The "Shale Gas Revolution": Developments and Changes, Chatham House Briefing Paper, London.

Tucker A (2012), "The New Power Map, World Politics After the Boom in Unconventional Energy", Foreign Affairs, December 19.

US DOE (2011), Shale Gas Production Subcommittee Second Ninety Day Report, Secretary of Energy Advisory Board, US Department of Energy, Washington DC.

Vihma A (2013), "The Shale Gas Boom”, FIIA Briefing Paper 122, Helsinki, February. 